\title{
震災復糔とインナーシテ们間题
}

一住宅政策の視点を中心に一

Revival from the Earthquake Damage and the Inner-City Problems

清水 亮

SHIMIZU Ryo

The Hanshin-Awaji Earthquake did great damage to inner-city area. A lot of discussions about the revival have been done in one year. In this paper, the revival in the inner-city area is considered especially focusing to the problem of aging society. The rapid aging in the inner-city community has become a social problem before the earthquake. Taking into account the influence of this situation on the damage of the earthquake, we have to consider this problem seriously aiming at the revival. Then this is an important problem common to the community formation not only in the struck area but also in a megalopolis of the future.

1.はじめに

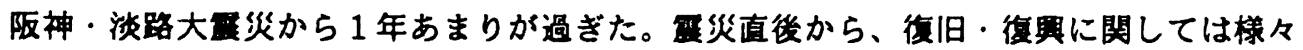
な問息点が指摘され、これに対処すへく諸々の提寨が行われてきた。防災・救助システム、 被災者支援、ボランティア、仮設住宅、被災建築再建、災害時の情報流通、復興まちうく り、等々。最近ではそれらに関する毒物も多数出版され、それぞれの立䭪から竬論が行わ れている。

本稿ではそうした復興に関わって多岐に渡り存在する問題の中からインナーシティエリ アにおける地域の高朎化問題に注目し、問題の発生状況を震災以前の地域社会の中に見て とる(1)。阪神地区におけるインナーシティ問題の発生、とりわけ地域の高踰化現象には 住宅という要素が大きな影零を及ほしていると考えることができる。この問題は、インナ ーシティ地区の住宅改善事業が十分に進行しないまま邚外に新規の大規模な宅地開発を行 ってきた従前の住宅政策の結果として見ることができるわけである。このように考えると インナーシティ問題を復興過程において解決していくためには、住宅政策という視点は重 要な践となろう。

そしてまた本稿では、ここに見られる問題が必ずしも被災地区固有の問題なのではなく、 大都市に共通した問題を弗んでいることを指摘する。インナーシティ問題は程度の差こそ あれ、各地の都市に見られる現象である。その意味で跟災復興の中でこの問題を考えると いうことは、現代日本の都市問題を真正面からとらえて論じることなのである。

\section{2. 得旧・復興過程に見られる生活格差}

今回の震災による死者は兵庫罢全体では6,279人に及んでいる（95.12.26見在消防庁調 へ）。年峆階耚別にこれを見ると、（表一1）のようになっている。一目瞵然、50歳以上 
の中高年跲者居に死者が多いことが見てとれる。これに ついては、若年層に比へて相対的に身体的不自由を抱え ていろこの目の人々が避鹳の幄れ等によって建物の下数 きになったり火の手から选げ切れなかったりしたという 原因がしはしは指摘されているが、しかしながら亭はそ う単䋥ではない。まず第一に、被害の集中した地域はち ようどインナーシティエリアが中心となっており、もと もとから高䑪化が進んた地域であった。そして第二に、 そうした高跲者世带が住んでいる家屋には一定の采年数 を経た木造建策物が多かった。実际、神戸市長田区のよ うに木造住宅が密集する地域では中高年跲者局の死 者の割合が他地域に比べて高くなっている[上野 1996： 128］。こうした要因が死者の年峆陵級別の分布に影

\begin{tabular}{|c|c|}
\hline \multirow{2}{*}{\multicolumn{2}{|c|}{ 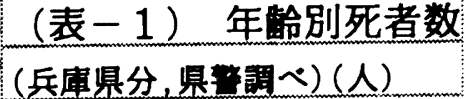 }} \\
\hline & \\
\hline 10歳末満 & 248 \\
\hline 10 代 & 310 \\
\hline 20代 & 469 \\
\hline 30 代 & 260 \\
\hline 40 代 & 466 \\
\hline 50 代 & 814 \\
\hline 60 代 & 1058 \\
\hline 70 代 & 1024 \\
\hline 80 代 & 728 \\
\hline 90葴以上 & 94 \\
\hline
\end{tabular}
を及ほしたわけである。

このことからわかるのは、筧以前におかれていた地城の状態が被害のあり方を強く规 定しているということである。高敛化の進展の度合いや住宅事情、あるいはコミュニティ の連带や成熟度などといった諸要素か、被害の程度を左右する重要な条件となったわけで ある。そしてさらにこのことは死亡者の問題にとどまらず、現に今生存し、復旧・復興に 向けての日々を送っていろ人々にもあてはまろことである。とりわけ、避篗生活において

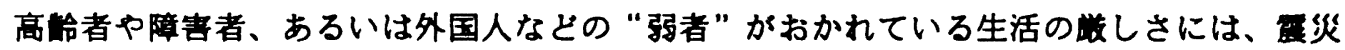
以前の生活格差がそのまま反映された形で、いや场合によってはそれが払大された形で表 れているといえる。

高峆者や障害者などで介殿の必要がある人々をどのように支授していくかという問題は、

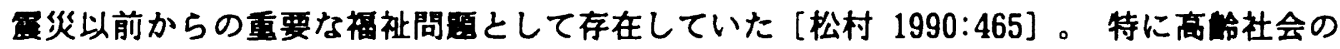

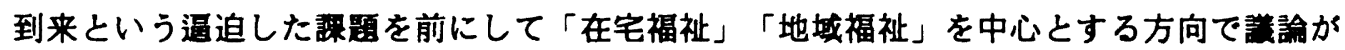
なされてはきたが、実除の福祉施策は崌々として進んでいない。そうした状況の中、今回 の夿災は発生した。平時においても支报システムが確立していない状態であるわけたから、 非常時において十分なサポートが行われるはずもない。高囹者は、避絜所ではグラウンド

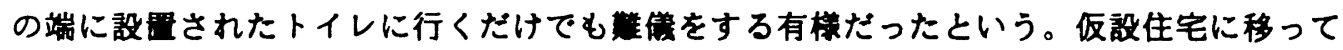
も玄関・浴室の段差や不便な買い物・通院をはじめ、不自由な生活は統いている[中过 1996:545]。必要な报助が得られずに困朋している人々は今なお少なくないのである。

被災地で起こっているこうした問题を、すへて震災という特殊事情に迡元して考えるわ けにはいかない。日本の大都市にみられるインナーシティ地区の状況は、共通して高跲社 会の福祉のあり方を課题としている。高哈化し、単身世带や夫䀦世帯となった人々を一体 どのようにケア・サポートしていくのかという問題は、その担い手論として家族というも ののあり方、行政のあり方、あるいは福祉ボランティアのあり方などを課題化している。

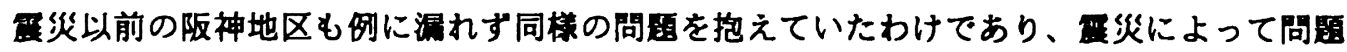
が一挙に表面化したに過ぎないのである。そして、復旧・復興の活動においては、この問 題は避けて通れない問影であると考えられる。なぜならば、この問題は単なる担い手論の 枠を超えて、住宅復興のようなハード面から地域住民間の相互扶助といったソフト面まで 
射程に含んた地域社会のありよう、社会学的な表現をするならば今後の「コミュニティ」 のあり方を左右するきわめて重要な要素を含んでいるからである。

\section{3. インナーシティ問題としての人口流出と戦後の都市定住政策 ${ }^{(2)}$}

ここでの議論の前提としていろインナーシティ問題を少し整理しておこう。日本の大都 市に見られるインナーシティ問題についてはこれまでに様々な䛰論の積み重ねがあるが、 本稿で注目するのは高峆化の問題である。そして、高峆化をもたらした原因としての人口 流出問題である。

阪神地区のインナーシティエリアに限らず、東京の都心地区などでも人口流出による地 域社会の高峆化という事腎は生している。この人口流出は特に若年煟から中堅ファミリー 眉といった人々に影著に見られる。転出の理由については仕事上の都合による移项を除く と、大雑把に括れは生活愣境の悪化と住宅そのものの質の問題ということになろう。良好 な居住㻴境と持ち家取得に县機つけられて、中堅ファミリ一居は邚外へと移住していった わけである。前者の居住環境の点については神戸の真野地区では公害問題、東京都心地区 では消費生活関連サービスの低下といった具合に、具体的には地域に固有な事情に扰って いる。一方、後者の住宅そのものの問題については地域固有の事情もさることなからら、戦 後の都市定住政策が及ほした影晋を無視することはできない。

戦後日本の都市住宅供給は、住居形式としての n DKモテルを開発し(1951年)、增え続 ける人口に対処した。n DKモテルとはn+DKまたはn+LDKという間取りの中に員 数に応じた家族を眍置していく手法であり、これによって住宅の広さは家族員数と対応す ることになる。すなわち、戦後の都市住宅は、梅淎的なライフサイクルを参照することに よって、居住者の年給から家族粠成、収入、ライフスタイル等の諸属性を引き出し、これ に合わせて住宅設計を行うというやり方で規格化されたのである。

戦後都市の住宅供給は、戦災によって極端に不足した住宅の確保に始まり、1960年代中 頃までは質より五を中心とした供給体制が持統する。この段階では「一世带一住宅」が目 標とされ、これに向けて公的な住宅供給体制が整備されていった。その後住宅政策は、量 的拉大から而の向上へと焦点がシフトしてゆく。ここに上述の n D Kモテルが組み込まれ、 $\mathrm{n} D \mathrm{D}=$ 家族モテルが钱後の都市型家族の典型となっていくのである。

家族形慧(員数)との対応関係を想定した n DKモテルによろ住宅供給体制は、所得階層 別住宅供給政策と相俟って、家族員数、並びに所得の変化に合わせた住み替えパターンを モテルとして提示することになる。これがハウジング・チェーンと呼ばれる規格化された 住み替えモテルである。この最も標準的なモテルとしては、公的には、公営住宅 $\rightarrow$ 公団・ 公社筫貸住宅 $\rightarrow$ 公団分譲 $\rightarrow$ 公庫／公団／公社の庭付き一戸建住宅というルートが準備され ていた。人々はそれぞれの属性的諸条件に船みて、このモテルの中のいずれかの段階に自 らを位置つけけていけばよかったのである。そして、それによって安定した都市定住者、す なわち都市の基本的階用として、都市の秩序に組み込まれていったのである。

けれどもここに二つの大きな問題点が隠されていた。一つは地価の問題であり、もう一 つは高給者の問題である。地価の問題は至って単純である。都市部の地価高閶によって建 設コストが上䒜し、安定した公的住宅供給が不可能になったのである。住宅建設が計画的 になされなければ、住宅財の配分を通して行われる都市定住の秩序化が崩塤するのは必至 
である。一方後者の問題であるが、上述のモテルには高踰者の存在は全く考虑されていな かったといっても過言ではない。寿命が延ひ、ライフサイクルが変化し、また住空間の編 成と接合した家族生成によって、都市には必然的に高峆者世带が析出してくることになる。 この高秢者局の世話を一体誰が行うのか。n DKモテルはこの問題を一切搭象する形で成 立し、展開してきたのであった。80年代中期以降、国家や自治体は福祉の切り楛てを断行 し、高まるニースとは逆行してこの問題に対する公的関与は消檑的な方向を示してきた。 したがって、高跲者扶養問題は劸い家族の双肩にかかってくることになる。ところが、す

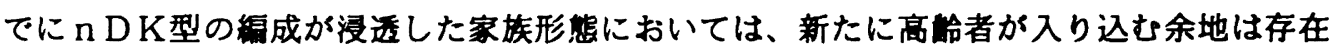
しない。これは端的に言って物理的余剩空間が存在しないということを指している。この

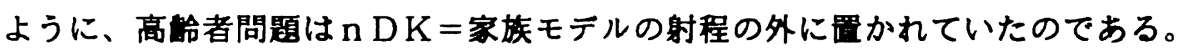

現在、核家族を基本とした㦷後の都市定住政策は臨界点に達している。都市はその外影 部においては依然としてn D Kモテルに基つく住宅供給がはかられて膨張倾向にあるもの の、中心部においてはすでに従来型の住宅政策では人口流出は抑えられなくなっている。 東京の都心地区などでは人口流出の結果、地域の高蛉化に加えて自治体の存統すらあやう くするほど人口の絶対数が減少し、自治体にとっても定住人口の回復が腎要な政策懒題と なっている。しかし、これといった有効な対策はまだ見つかっていない。

\section{4. 神戸の都市計画とインナーシティ問題}

上述のように、インナーシティエリアにおける中堅ファミリー層の流出とそれに伴う高 龄化という現象は、これまでの都市の定住政策の結果であるということができる。被災地 神戸においてもこのことは変わらない。

（表－2）は神戸市の人口の推移である。表からわかるように中央 4 区（湍区・中央区

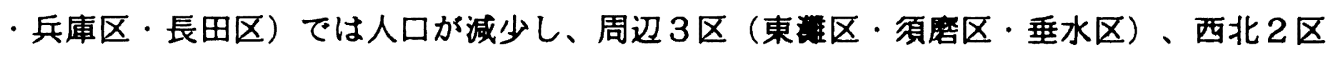
（西区・北区）では人口の急增が見られる。こうした対照的な動きは、ひとえに神戸市の 都市計画の結果であるといえる。

宮崎市政は六甲山系の宅地開発事業之臨海埋立事業とをリンクさせた都市開発を行った。 市当局が自ら山を削り海を埋め立てるという神戸特有の公共テベロッパー方式による都市 開発は、須磨ニュータウンや西神ニュータウンといった大規模な宅地を邚外エリアに造成 した。このニュータウンに流れ込んだのが中堅ファミリーを中心とした首であった。市の 当初の目論見では、中央 4 区を中心とする既成市街地の人口は䊒持したまま、ニュータウ ンの住民としては他地域からの人口流入を見込んでいた。ところか、現実にはニュータウ ンへと流れ込んだ住民の中には、良好な居住生活国境を求めてインナーシティエリアから 脱出してきた20３0歳代の若年・中堅ファミリ一層が多く含まれていたのである。

（表－2）地域別人口の推移（神戸市1965～1990）単位:万

\begin{tabular}{l|r|r|r|r|r|r}
\hline & 1965 & 1970 & 1975 & 1980 & 1985 & 1990 \\
\hline 中央4区 & 76.2 & 71.8 & 64.0 & 56.4 & 53.2 & 50.6 \\
周辺3区 & 36.5 & 44.4 & 51.6 & 55.2 & 59.1 & 61.4 \\
西北2区 & 9.0 & 12.8 & 20.4 & 25.2 & 28.8 & 35.7 \\
\hline 全市 & 121.7 & 128.9 & 136.1 & 136.7 & 141.1 & 147.7 \\
\hline
\end{tabular}

国勢調㚗テータより 
確かにそれまでの既成市街地は不良住宅が密集し人口も過密状態にあったわけだから、 邚外エリアにおける大規模な宅地開発は人口分散化の奻果をもたらしたととらえることも 不可能ではない。けれども、単なる人口の絶対数というのではなく年給や所得といった諸 要素を考成するならは、このニュータウン開発がインナーシティエリアと郊外エリアとの 間に著しい住民虽性バランスの偏向を生み出したことは明白であり、インナーシティエリ アの高囹化を助長した一大要因となったことは間逗いない。一連の開発事業を神戸市全体 の都市計画として見るならば、あくまでもこの人口移動がインナーシティエリアの再開発 事業の結果としての人口分散ではなかったことを見落としてはならないのである。

地域社会活性化の中心的担い手居であり、なおかつ人口再生産の锤点からむコミュニテ イの䊒持にとって重要な存在である中堅ファミリー層が流出していった結果、インナーシ

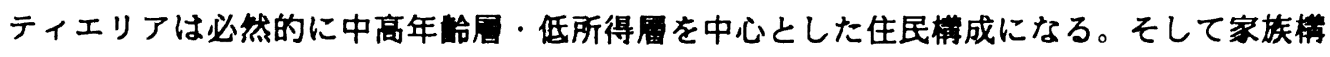
成の点についても、子世代の他出が進むにつれて夫唰世带や単身世带が增加してくる。 えて言うならば行き域のない人々が滞留することになるのである。こうした地域では住宅 のストックが低水泍であり、転出により空き家になった住宅に入ってくる人があってもそ れはまた中高年峆層・低所得層であったりする。このようにインナーシティエリアの衰退 は進行していったわけである。

こうしたインナーエリア問題の深刻化に対して、いち早くその解決に向けての運動を起 こしたのが真野地区のまちつくり運動である。真野のまちうくり運動は全国的に有名であ り、多くの研究者が紹介を行っているので詳䎩についてここで述へろことはしないか、、神 戸市のインナーシティ䦓題への取り組みを見るためにこく簡単に触れておくことにしょう。

\section{5. 真野のまちづくり運動と神戸市のインナーシティ再開発政策 ${ }^{(3)}$}

神戸市長田区の真野地区では、上述のようなインナーシティ問題の進行が他地域に比へ てきわめて急速に進展した。人口の娍少は1960年からはじまっており、1990年までの間に 13,377 人か 55,731 人へ、世带数は3,223世帯か52,098世帯へと擏減している。実に人口 にして57.2\%、世帯数にして34.9\%が他所へ流出しているのである。この激しい移動の結 果として、高秢者世带の比率、単身世带の比率なども著しく高い値を示すようになる。も ちろん背景としては、真野地区においては老朽化した木造狭小の不良住宅の比率が高いと いうことが大きく影要している。

こうした劣悪な住宅事情に加えてこの地区は住工混在地区であり、公害問題が発生して いた。工場廃水によって地区を流れる河川が污染されたり、大気污染による喘息が住民に 蒙延するといった深刻な事遙を前にして、居住珢境の確保を目指す公害反対運動が決起さ れた(1965年)。これが真野地区のまちつくりの端楮である。この運動が一定の成果をあげ て公害防止協定が楴結され、環境の改善が見られるようになると、次には粶化・地域福祉 ・まちつくりへと運動は展開していった。70年代後半からはまちつくり組伡が本格的に立 ち上げあられ、土地利用・道路整備・建物整備などがきめ湅かく権想されていくようにな る。市の側でもこうした住民主体の運動を先佂的な事例としてバックアップを行った。当 時は「まちつくり」そのものの手法が未確立な状態であり、市としては真野の事例をモテ ル化することでまちうくりのノゥハウを蓄積しようとしたわけである。

真野のまちつくりは、異常なまでの人口流出に伴う地域の長退と公害問題が、地域での 
㫷らしの上でもはや無視しえない深刻な事態を招いたところから始まっている。そして、 何よりもこの運動を特徵つけけてろのは一貫した住民の側の主体性であり、コミュニティ の連帯や相互扶助をとことんまで重視している点である。市が様々な形でこの運動を支え たのも、こうした住民主体の方法こそがまちつくりのモテルとなりうろと考えたからであ る。けれども、事意はそう容易には運ばなかったのである。

神戸市は当初、真野地区と同様の問原を抱える他の既成市街地にこの真野モデルが応用 されるものと考えていたようである。こうした発想は、真野地区をまちつくりの理想的な 先殹的事例として稆介してきた研究者にも共有されていたものと思われる。たか、他の既 成市街地では真野のような活発なまちつくり活動は展開しなかった。その理由としては一 つには他地域では真野ほど事態が䫏在的に深刻化しておらず、住民サイドに問題意識が淢 かったということが挙げられよう。問題意識が希薄である以上、こうした地域におけるま ちつくくり活動はまずは住民の主体化から始められなくてはならないことになる。行政はワ ークショップなどの手法を駇して住民にまちつくりへの参加を勘機づけていくわけであ ろが、このようなやり方は結局は住民主体の方法とはいえないし、また現に十分な成果も あがっていない。かくして神戸市のまちつくり政策は、90年代に入ると方針転换をはかる ことになる。

神戸市は1989年に『神戸市インナーシティ稳合基塂本計画』を策定する。そこでは、 执点開発型のまちつくり方式が採用されており、ハーパーランド整借事菜や新長田师前再 開発事業など、19のリーティング・プロジェクトが提示されている。これらのプロジェク トを柱にして、行政主望によるまちつくりを行おうというのが神戸市のねらいである。こ うした方猃夽换は、一般の既成市街地では真野地区に見られたような住民の主体形成が行 われず、まちつくり遇動による市街地整借が㜊々として進まないことが原因であったと思 われる。それでも市は、ブロシェクトにリンクする周辺地区のまちつくりにおいて、市の 㦈員を継続的に現地に通わせるなと、真野地区で培われた手法を様々に取り込んでいる。 この中で特に重要なのはまちつくり協㦈会の設立と、まちつくりコンサルタントの派这で あろう。住民が自らの要求を実現すへく行政の支嗳を求めるためには、個々の住民がバラ パラに意思を表明していても㙁はあかない。そこには、ある一定のまとまりをもった地城 住民相互間のまちつくりに対する合意形成が不可欠である。まちつくり咕譜会は住民主体 の運営で合意形成を行い、その合意された意思をもって市との交涉に当たる組繶として位 专づけられるものである。また、実現性のある具体的なプランを市に提示していくために は住民自身の㑡にまちつくりに対する一定の専門的知誐が必要であり、まちつくくりを総合 的にマネージメントしつつ、そうした知識を住民に提供してともにまちつくりを考えてい く存在として、コンサルタントは重要な位置を占めているのである。

リーティンク・ブロジェクトを既成市街地整借の呼び水にしようとする、いわば匦点開 発連動型のまちつくりともいうへき手法は、上述のように確かに手法としては真野地区で のノウハウが取り込まれたものとなってはいる。たか、事業そのものとしてはあくまでも 行政主䓕で行われるリーティング・ブロシェクトの実施が中心的であり、まちうくりはそ れを前提として進められることになる以上、副次的な位圈つけになりがちである。そして、 まちつくり協償会の活動を通して住民が碽極的にまちつくり運動にかかかり、地域の担い 手として主体化していくということが必ずしも十分に目的化されていないという点でも真 
野のモテルとは大きく異なっている。このように、90年代に入っての神戸のまちうくり政

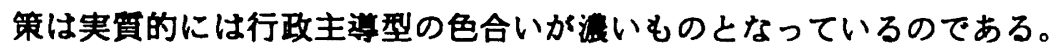

\section{6. インナーシティエリアの復興計画}

神戸市のインナーシティエリアは、これまで述へてきたような状況の下に今回の震災に

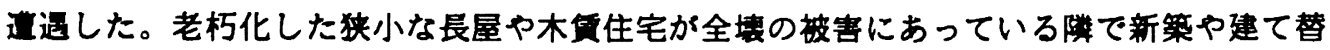
え住宅が㙰を逃れているという今回の被害状況を見ると、不良住宅の改善事業がなかなか 進まなかったことが罡災の被害を扗大したように思えてならない。このように考えると、 盛災復興の過程ではインナーシティエリアにおける不良住宅の整備事業がひとつの重要な ポイントとなってくる。これは老朽化した木造住宅が甽棲・焼失したという反省に立って、 地霞に強い頑強な粠造をもち、同時に火災にも強い不然性を備えるという防災的镜点から の課題であるわけだが、他方では高峆化問原への対応策としての要素を持つものである。 すなわち、床面栍・間取り等の点で良好な住宅ストックを形成することによって中婜ファ ミリー居の入居を促し、延いては住民属性のバランスを図ることが可能になるからである。

神戸市が1995年6月に提示した「神戸市復興計画」においても「震災では既成市街地域 全域が大きな被害を受けたが、特に生活道路など身近な公共施設の整備が遅れ、老朽化し た木造住宅が密集するいわゆるインナーシティでは建物の㑬俵や延焼などにより大きな被 害が集中した」[神戸市 1995:132] と述へられており、インナーシティエリアの整估の 䐅れは明碓に意識されている。ではこうした認識をふまえた上で策定された復興計画はど のようなものであろうか。

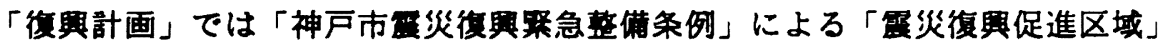
$5,887 \mathrm{ha}$ ）を特に総合的なまちうくりの必要な区域としてとらえ、これを「都心地域」 「東部市街地」「西部市街地」に分けてそれぞれに地域復興の方向性を示している。そし てそこでは1989年に策定された「神戸市インナーシティ総合整借基本計画」の際にとられ た撽点開発方式が継承され、三地域合わせて計18の復與プロシェクトが提示されている。 これらのプロジェクトの中には89年の整塂基本計画に盛り込まれていたリーティンク・プ ロシェクトがてまま引き継がれたものも含まれている。一方、震災の被害が特に著しか った「重点復興地域」（約1,225ha,24地域）においては土地区画整理事業や市街地再開発 事業などが具体的に計画され、まちつくりコンサルタントの派遣等の支援を受けながらま ちつくりを樌極的に進めていくとしている。

この「復興計画」は、全体としてみると行政主導の拠点開発の色彩が強く、“白地地域 ”と呼ばれる「重点德興地域」に指定されなかった残りの「霞災復興推進区域」の復興方 針については行政サイドからは実質的に無策に近い状態であるなと、問題点も指摘されて いる[広原 1996:119-120］。また手法という点についても、真野のまちうくり運動の時 のような住民の主体性を尊重したやり方とは異なったものである。碓かに復旧という钼点 からすれば一日も早い恒久住宅の建築が望まれろわけだから、権利調整の話し合いなどに 延々と時間をかけて合意を形成していく住民主導のやり方が必ずしも適当だというわけで はない。けれども、ここでこうしたまちうくり手法に対する一定の判断を行う前に、考え なければならない一つの重大な問題が存在しているように思われる。それは震災以前から 存在していた問題であるところの地域の高崘化をどのような形で解決しようとするのかと 
いう問題である。

この問題には大きく分けて二つの側面がある。一つは、高岭化した地域社会に若年層・ 中堅ファミリー層の呼び戻しによって活性化を図ろうとするまちつくりレベルの面であり、 もう一つはすでに高秢者となった人々のケア・サポートをどのような形で行っていくのか という福祉レベルの面である。そしてここで強調したいのは、この二つの側面が復興遇程 においては実は住宅問通として接合してくるということである。

コミュニティの活性化という課題にとっては、邚外エリアに流出した中堅ファミリー層 をいかにしてインナーシティ部に呼び戻すかが重要な鍵となってくる(4)。それには受け 皿となる良質な家族向けの住宅ストックが必要であり、まちつくりの中でこうした住宅を いかに地域内に建設していくのかを考えなければならない。一方で高輞者ケア・サポート の担い手諭の課題にとっては、「在宅福祉」へと向かう全体の流れの中で考えられる選択 肢としての家族・コミュニティ・福祉ボランティア (5) などをいかに組み合わせて活用し ていくのかが鍵となってくる。この担い手論をどのように考えるかは諸説に別れるところ であろうが、日本の高制者福祉の現状を見るにいずれにせよ子世代家族というものが重要 な位㯰を占めてくろことは論を待たないであろう。してみると、コミュニティ活性化と高 龄者福祉の担い手の両問題は親子世带の同居・陆居・近居型の住宅供給をいかに促進する かという点で連接してくる。

これらの論点について、神戸市の「復興計画」では住宅復興の問題と高略者裍祉の問題 とは基本的にはリンクしていない。

住宅復興が緊要な課題であるという認瀻は住民・行政の双方に存在するし、「復興計画」 の中にもそのことは認められる。そしてそのための方策として実に多様なメニューが用意 されている。良質住宅の早期大量供給や住宅の自力更新・取得・建設等の支援などを様々 な制度を駆使しつつ行っていくことが復興計画」では明示されている。この中には高跲 者等に対する住宅支援に関する言及もあるのだか、そこではいわゆる“高峆者向け住宅” の供給が主である。福祉問題との関連では「地域社会で安心して生活が送れる福祉サービ ス等に配虑」[神戸市 1995:10］するという考え方が記述されているものの、実現につい ては何ら具体化されていない。

一方、福祉については「在宅福祉の基盤である生活の㘿の衰失や、家庭・地域嫄境の変 化による介護・峑育機能の低下や負傷、心身機能の低下など、霞災により生じた新たな福 祉需要に対応するため、福祉施設の早期復旧を四り、要援讙者への従来のサービスの払充、 必要な新たなサービスを実施し、生活全体の安定を図る」[神戸市 1995:23] として、ホ ームヘルプサービス、ティサービス、ショートスティの执充などを事業として計画してい るが、特段にまちうくりや住宅復興と関連つけるような方性は見当たらない。

\section{7. おわりに}

これまでの日本の都市定住政策においては核家族が基本単位とされており、これがゆえ に都市においては高龄者は子世帯と別居する傾向が生じている。若年層や中堅ファミリー 層が流出してインナーシティエリアに高铃者の夫婦世帯や単身世帯が析出してくるのも、 こうした定住政策の帰結であるといえるわけだが、この傾向は高㗐者ケア・サポートの担 い手として子世代家族に期待するという発想に限界をもたらしてきた。復興を論じるに際 
しては、こうした従前の問題点を見据えて取り組んでいく必要がある。正災以前の状況に 「復旧」しただけでは根本的な問題解決にはならない。

今後、真野地区のようなコミュニティの粱密な連帯や相互扶助によって高峆者問題を克 服していこうとするならば、住民の主体化が前提条件となる。しかしなから震災以前の他 地域でのまちつくり運動に見られるように、住民の主体化は容易ではない。震災直後の消 火活動をはじめとしてその後の避嚾所での活動など、碓かに真野地区のコミュニティのカ は実に見事なまでに発揮されたし[阪神復興支援NPO編 1995]、この事例に注目してコミ ユニティの連带を強調する論潮もある。だがこれはあくまでも30年間に渡るまちつくり活 動の成果なのであって、この連带をいきなり他地区に求めることはできない。その意味で は単に真野地区の事例を称賛するたけでは不十分である。

言うまでもなく、住民主体のまちつくくりという考え方はきわめて重要なむのであり、コ ミュニティの連带もこうした住民主学の地道な活動の中で策き上げられていくものであろ う。これについては復興に対する提言を行っている様々な諭者の大半が触れている点であ ろ。だがもう一歩踏み込んで、コミュニティの活性化を具体的なまちつくりの内容、とり わけ住宅問題と関わらせて論じる㦈論は、数ある住宅復興論の中でも今一つ少ないように 感じられる ${ }^{(6)}$ 。

インナーシティエリアの霞災復興における住宅問題やコミュニティ形成の問題を地域の 高峆化との関わりで論じるということは、そのまま今後の都市の高峆者福祉問題を論じる ことに渋がっている。神戸をはじめとした被災地の復興過程におけるまちつくり・コミュ ニティ形成で問われているのは、当該地城に固有の問題にとどまらず、これからの都市そ のもののあり方なのである。

<註>

(1)本稫の議諭は、笛者が参加した神戸市でのヒアリング調査（1995年7月23〜27日、8月24〜26日、研究 代表者：東京大学似田貝香門数授)で得られたテータをもとに展開している。本洅㚗では神戸市、テ ント村自治会、ボランティア団体、まちつくり協榙会、まちつくりコンサルタント等を対象としたヒ アリンクかが行われた。したがって本稿の償詥では、被災地の中でも主に神戸市のインナーシティエリ アにおける得興を念頭においていることを断っておく。

（2）本章での戦後都市定住政策についての㦈噙は[似田貝 1994]を参考にしている。

（3）神戸市のインナーシティ政策における真野地区のまちつくり運動の位置つけに関する本章での議諭は 主に[広原 1996:85-114] に败っている。

(4)我々がヒアリングを行った長田区のN地区では、震災以前から「链力あるまちつくり」事莱が行かれ ており、公園の整備などの活動を行っていた。この地区でも中堅ファミリー層を中心とした人口流出 が進んでおり、住民としては、道路・公園の整储等、住即境の改善を図ることによって、若い人に㷌 ってきてもらいたいと考えていたという。

(5) 日本においてはボランティアが末成然であり、コミュニティの中にボランティアをとのように連接さ せていくかという課題は今回の震災の中から出てきた新しいテーマである。俱解を恐れずにいえば従 来のコミュニティ論は居住者のみに関心を厸ってきたといえろか、地域の高岭化問題や障害者福祉の 問頵においてノーマライセーションという考え方を真剩に追求していこうとするならは、居住者とい 
う枠を恝えた多样な主体に目を向ける必要があろう。

(6) 復興道程の現時点での住宅問题の関心は、いかにして家災以前に居住していた地域に戻るための受け 皿住宅を建設するかという点に力点があるように思われる。長田区N地区においても「ここに住み紿 けたい」と希望する住民は9啰を垫え、このための箱として、住宅の共同化をはじととした住宅確保

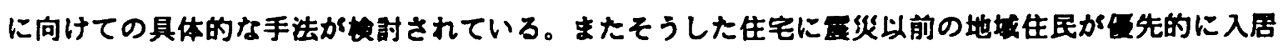

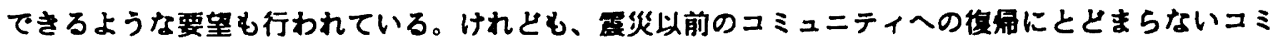
ニニティの活性化（中堅ファミリー届の呼び戻しなと）に関しては、今の段䐗ではそこまで目を向け ろ余裕が住民側に十分にあるわけではないというのが玩状である。

<夸考文韵>

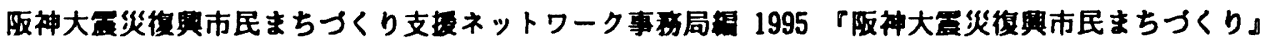

Vol.2 学芸出版社

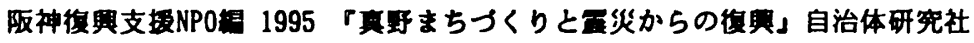

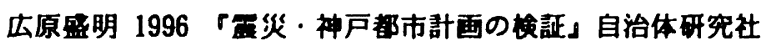

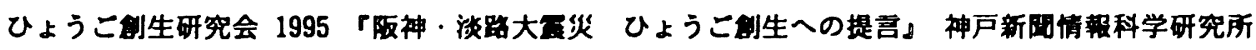

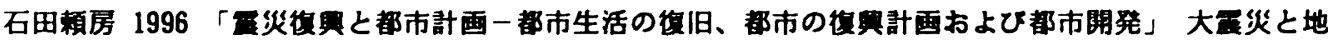
方自治研究会细『大家災と地方自治一得興への提言一』自治体研究社 pp.39-51. 神戸市 1995 「神戸市復舆計画」

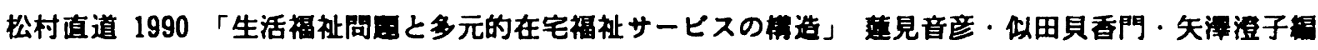
『都市政策之地域形成一神戸市を対象に』東京大学出版会 pp.461-478.

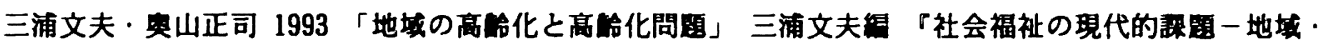

高峆化・禓祉一』 サイエンス社 pp.89-119.

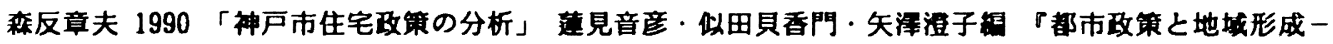
神戸市を対象に』東京大学出版会 pp.363-398.

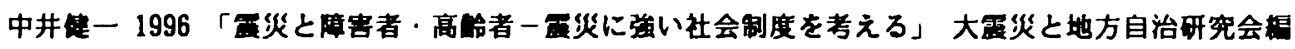
『大震災と地方自治一復興への提言一』自治体研究社 pp.154-163.

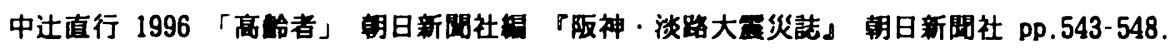

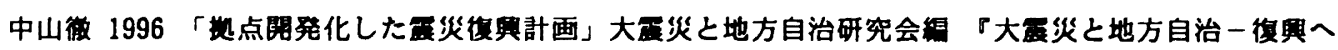
の提言一』自治体研究社 pp.65-76.

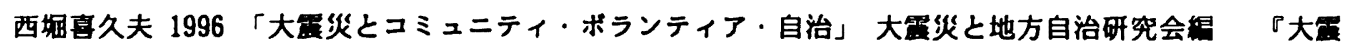
災と地方自治一復興への提言一」自治体研究社 pp.181-197.

似田貝香門 1994 「現代都市の住宅政策一その社会学的分析」高棉勇说・菊池美代志编「今日の都市社 会学』学文社 pp.265-283.

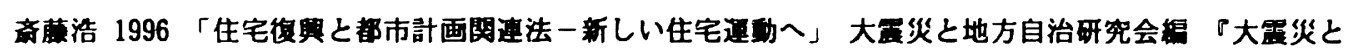
地方自治一復興への提言一』自治体研究社 pp.105-123.

坂和章平・中井康之・森恵一・岡村泰郎 1995 『㺼炎得興まちつくりへの模案』都市文化社 高田昇 1996 「住宅の再建」朝日新聞社編「阪神・波路大震災㖁」朝日新闑社 pp.605-620.

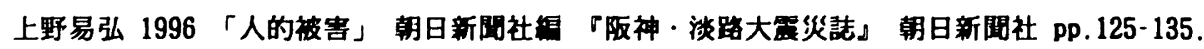

